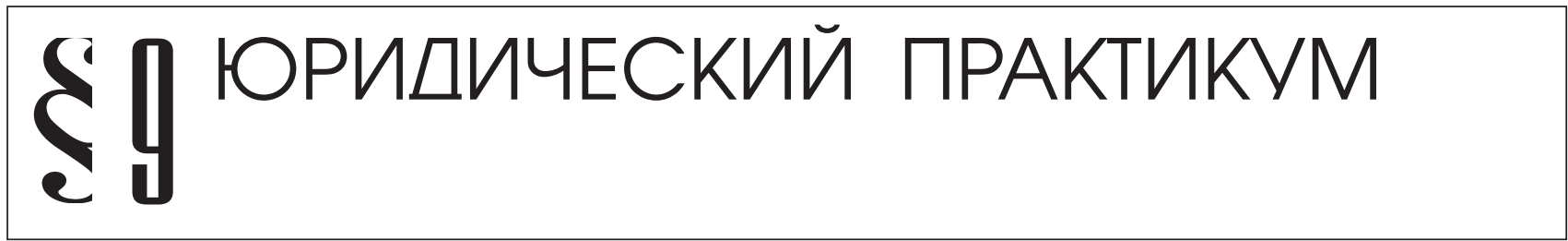

\title{
ВЫБОР ПРИМЕНИМОГО ПРАВА И АРБИТРАЖНЫЕ ОГОВОРКИ В ДОГОВОРЕ ПЕРЕСТРАХОВАНИЯ
}

\begin{abstract}
Аннотация: Автор анализирует вопросы выбора применимого права в договорах перестрахования. В том числе анализируются способы разрешения споров и приводятся примеры возможных арбитражных оговорок, применяемых в договорах перестрахования, осложненных иностранных элементов. Показано, что урегулирование спорной ситуации, возникщей между сторонами договора перестрахования, осложненного иностранным элементом, зачастую зависит от того, какому правопорядку подчинен данный договор, а также какой орган и способ разрешения споров выбрали участники договора.

Ключевые слова: перестрахование, lex теrсаtoria, негосударственное право, Римская конвенция 1980 г., Регламент Рим I, применимое право, разрешение споров, медиачия, арбитражная оговорка, ARIAS.
\end{abstract}

$\Pi$ ерестраховочные отношения являются неотъемлемой частью международного страхового рынка, являясь тесно связанными с внешнеэкономической деятельностью. Современный мировой рынок перестрахования в значительной степени подвержен процессами глобализации.

Трансграничный характер отношений перестрахования обуславливает интенсивное проникновение прогрессивных технологий на отечественный страховой рынок, который в настоящее время переживает эпоху бурного роста. Российские компании, являясь участниками перестраховочных отношений заключают международные коммерческие контракты (договоры перестрахования), осложненные иностранным элементом либо в качестве перестрахователей либо, что значительно реже, в качестве перестраховщиков.

Многие российские страховые организации для защиты рисков, принятых на страхование, используют перестраховочные емкости зарубежных рынков, рассматривая данные рынки как более надежные, чем размещение на российском рынке.

Доля страховых премий по договорам, переданным российскими страховщиками перестраховщикам - нерезидентам Российской Федерации, увеличивается с каждым годом. В настоящее время возможно констатировать факт укрепления тенденции, направленной на повышение доли иностранных перестраховщиков в структуре страховых премий, переданных в перестрахование. ${ }^{1}$ Только за 2009 г. количество страховщиков-резидентов, принимающих риски в перестрахование сократилось на $11 \%$, в 2010 году данная тенденция сохранилась.

С 01 января 2012 г. вступили в силу изменения, принятые в Закон РФ от 27 ноября 1992 г. №4015-I «Об организации страхового дела» в июле 2010 г., касающиеся увеличения минимального уставного капитала страховой организации, имеющей лицензию на осуществление деятельности по перестрахованию, до 480 млн. рублей. В ноябре 2011 г. в Государственную Думу РФ был внесен законопроект №625509-5 «О внесении изменений в Закон Российской Федерации «Об организации страхового дела в Российской Федерации» в целях приведения норм Закона в соответствие международной практикой регулирования страховой сферы. В законопроекте предложена новая редакция ст. 13 Закона «Об организации страхового дела в Российской Федерации», посвященная вопросам перестрахования. В частности, п. 2 ст. 13 Закона в редакции законопроекта определяет, что допускается деятельность по перестрахованию с участием иностранных страховых и перестраховочных организаций, полу-

\footnotetext{
$1<$ Доклад о развитии страхового рынка в России в 2009 году - 1 полугодии 2010 года>// Федеральная служба страхового надзора. Доклад опубликован на сайте Федеральной службы страхового надзора PФ. URL: http://www.fssn.ru/www/site.nsf/web/ doc_21042011152741.html (09/01/2012)
} 
чивших в соответствии с национальным законодательством страны регистрации лицензию на осуществление такой деятельности и соответствующих требованиям пункта 8 ст. 13 Закона. При этом, п. 8 ст. 13 Закона в редакции законопроекта устанавливает, что передача рисков (части рисков) в перестрахование иностранному страховщику возможна только в случае наличия у него рейтинга международного рейтингового агентства не ниже уровня удовлетворительной кредитоспособности (финансовой надежности), а также признанного в соответствии с национальным законодательством в стране регистрации и Российской Федерации.

Нельзя не согласиться с мнением участников финансовых рынков, что представляется абсолютно недопустимым создавать административные барьеры при входе на рынок, при наращивании масштабов бизнеса, путем законодательных инициатив, которые, безусловно, будут тормозить предпринимательскую активность и приведут к стагнации. В странах, в которых такие ограничения действуют (Казахстан, Португалия, Дания, т.д.), данные барьеры не способствуют развитию перестрахования. ${ }^{2}$

Представленная новелла рассматриваемого в Государственной Думе законопроекта существенным образом может оказать влияние на дальнейшее развитие рынка перестрахования в Российской Федерации в сторону его сужения и ограничение сотрудничества с зарубежными партнерами по перестрахованию, т.к. возможность заключения договора перестрахования ставится в зависимость от наличия у перестраховщика рейтинга международного рейтингового агентства.

В этой связи полагаем, что тенденция по сокращению перестраховочных емкостей на национальном рынке в 2012 - 2013 годах сохранится.

В 2012 - 2013 гг. на российском рынке перестраховочных услуг будет сохраняться тенденция укрупнения бизнеса, обусловленная как внешними, так и внутренними факторами. Среди внешних факторов можно выделить: ужесточение требований к минимальному размеру уставного капитала страховых и перестраховочных организаций, вступление России в ВТО, а также процессы реорганизации компаний, входящих в различные страховые группы. Внутренним фактором продолжит оставаться оптимизация деятельности страховых компаний за счет сокращения операционных и расходов на ведение дела (аквизиционные расходы).

Несмотря на то, что договоры международного перестрахования имеют широкое распространение во всем мире, тем не менее, представляется, что не все те-

\footnotetext{
2 Зимин A.B. Кому нужен старый комод, или Снова о перестраховании// Юридическая и правовая работа в страховании. - М.,
} 2012. - № 4 (32). - с. 34 оретические и практические вопросы урегулированы в достаточной степени, в частности, о применимом праве по договорам перестрахования, органах и способах разрешения споров.

Ввиду того, что материальное право различных государств существенно различается, в международных торговых (в широком смысле слова) отношениях конкретный результат правового регулирования зачастую зависит от того, какому правопорядку подчинен данный контракт. Объем и пределы ответственности сторон по договору, действительность договора и считается ли он заключенным вообще и т.д. - вот вопросы, которые несовпадающим порядком решаются в разных странах. ${ }^{3}$

Большая часть современного торгового права происходит от lex mercatoria, международного свода торговых норм, правил и обычаев.

Концепция lex mercatoria при всем многообразии интерпретации ее содержания все-таки имеет во всех случаях общий стержень. Это, прежде всего, выведение права международной торговли за рамки какой-либо конкретной правовой системы, будь то международная или национальная, с одной стороны, включение в его состав предписаний неправового характера, с другой стороны. Наконец, это отказ от традиционных коллизионных принципов как основного инструментария МЧП и замена их «вненациональными», «автономными» средствами регулирования внешнеэкономических связей и разрешения возникающих в этой сфере споров. ${ }^{4}$ Полагаем, что термины «вненациональное», «автономное» средство регулирования можно сопоставить с понятием «негосударственного права». Под «негосударственным правом» (франц.: droit non etatique; англ.: non-State body of law; нем.: nichtstaatliches Regelwerk) имеются в виду, в частности, акты международных межправительственных и неправительственных организаций, в том числе акты, не имеющие обязательной силы для государств и частных лиц (например, подготовленный Международной торговой палатой свод правил по толкованию международных торговых терминов - «ИНКОТЕРМС», Принципы европейского договорного права, Принципы международных коммерческих договоров - Принципы УНИДРУА).

В теории lex mercatoria получили отражение существующие тенденции и результаты взаимодействия права с его материальной основой в части международных экономических (преимущественно торговых в широком смысле слова) отношений, растущая динамика

\footnotetext{
${ }^{3}$ Ануфриева Л.П. Международное частное правом: в 3-х т. Особенная часть, Том 2- М.: Издетельство БЕК, 2002. - с. 202

${ }^{4}$ Ануфриева Л.П. Международное частное правом: в 3-х т. Особенная часть, Том 2 - М.: Издетельство БЕК, 2002. - с. 220
} 


\section{Право и политика $4(160) \cdot 2013$}

мирохозяйственных связей и определенное отставание развития национального законодательства, обеспечивающего их регулирование. ${ }^{5}$

Существует два главных основания применения lex mercatoria. Одним из них является воля сторон: стороны могут установить, что тот или иной обычай имеет для них обязательное значение, включая его текст в договор (интерполяция). Вторым основанием применение обычая является его использование государственным судом или арбитражем в том случае, когда, хотя стороны и не указали на его применение, однако обычай был признан судом или арбитражем в качестве источника регулирования отношений сторон по договору. ${ }^{6}$ Полагаем, что правомерно следующее утверждение: lex mercatoria - это концепция, обосновывающая наличие специальной, обособленной от национальных систем права, системы правового регулирования транснациональных сделок. Согласно данной теории международная торговля, прежде всего, должна опосредоваться международными договорами и международными торговыми обычаями. Таким образом, одной из главных областей применения lex mercatoria являются договоры, урегулированные международными обычаями и практикой делового оборота, например, договор перестрахования. Использование lex mercatoria при разрешении споров возможно в связи с международным характером договоров перестрахования, осложненных иностранным элементом.

Суды часто стали сталкиваться со случаями, когда соглашение сторон устанавливает применение к их спорам из договора документов «вненационального» характера (lex mercatoria). Однако возникает вопрос, могут ли стороны договора выбирать в качестве применимого права «вненациональные» источники права, так называемое «негосударственное» право, не применяя к урегулированию отношений из договора императивных норм материального права той или иной юрисдикции согласно правилам выбора применимого права?

Согласно принципу автономии воли стороны при заключении договора могут свободно избрать применимое право к обязательственным отношениям, вытекающим из сделки (lex voluntaris). Ряд международных соглашений закрепляет изложенный подход о возможности свободного выбора закона, подлежащего применению на основе автономии воли сторон (ст. 7 Гаагской конвенции от 22 декабря 1986 г. «О праве, применимом к договорам международной купли-продажи товаров»; ст. 11 (е)

\footnotetext{
${ }_{5}^{5}$ Ануфриева Л.П. Международное частное правом: в 3-х т. Особенная часть, Том 2 - М.: Издетельство БЕК, 2002. - с. 219

${ }^{6}$ Сироткина О.В. Принципы европейского договорного права: история создания, статус и основные положения // Сборник научных трудов. Серия «Право», выпуск № 1 (5). - СевКавГТУ, Ставрополь, 2003. - с. 5.
}

Соглашения о порядке разрешения споров, связанных с осуществлением хозяйственной деятельности (Киев, 1992 г.)). До 17 декабря 2009 г. аналогичный принцип устанавливался ст. 3 Римской конвенции 1980 г. «О праве, применимом к договорным обязательствам», действовавшей на территории государств, ратифицировавших ее. Согласно статье 29 Регламента (ЕС) №593/2008 Европейского Парламента и Совета от 17 июня 2008 г. данный нормативный акт в полном объеме приобрел юридически обязательную силу и прямое действие в государствах-членах ЕС, в том числе в их национальных судах с 17 декабря 2009.

Остановимся более подробно на характеристики данного акта, имеющего прямое действие на территории государств Европейского Союза, кроме Дании, в отношении коллизионного регулирования в контексте применения к договорам международного перестрахования.

Вопросы, регулируемые принятым Регламентом, получившим название в ЕС «Рим I», в прошлом регламентировались в ЕС специальным международным договором между его государствами-членами - Римской конвенцией 1980 г. «О праве, применимом к договорным обязательствам». Таким образом, с этого момента Римская конвенция фактически утратила силу на территории ЕС, кроме Дании (ст. 24 Регламента). Важно отметить, что Регламент носит универсальный характер и право, указанное Регламентом, применяется даже в том случае, если оно не является правом одного из государств-членов. В настоящий момент положения Регламента непосредственно распространяют свое действие на 26 из 27 действующих государств-членов Европейского Союза.

Регламент «Рим I» применяется в ситуациях, содержащих конфликт законов, к договорным обязательствам в гражданской и торговой сфере. Данный акт не применяется, в частности, к налоговой, таможенной и административной сферам. Дополнительно из сферы применения Регламента исключаются вопросы, связанные с обязательствами:

- вытекающими из семейных отношений,

- вытекающими из режимов имущества супругов и режимов имущества в рамках наследования;

- возникающими на основании переводных векселей, чеков, простых векселей, а также других оборотных ценных бумаг.

Также исключаются из сферы регулирования арбитражные соглашения и соглашения о выборе суда; вопросы правового регулирования обществ, ассоциаций и юридических лиц.

В отношении договоров перестрахования Регламент «Рим I» действует с некоторыми изъятиями (ст. 7 Регламента).

Право, подлежащее применению к договорам согласно данному Регламенту, регулирует, в частности: 
- его толкование;

- исполнение возникающих на его основании обязательств;

- в пределах полномочий, предоставленных рассматривающему дело суду его процессуальным правом, последствия полного или частичного неисполнения этих обязательств, включая оценку убытков в той мере, в какой это регулируется правовыми нормами;

- $\quad$ различные способы прекращения обязательств, а также исковую давность и утрату права на основании истечения срока;

- последствия недействительности договора.

Отметим, что замена Римской конвенции Регламентом «Рим I» имела перед собой несколько важных целей, в частности:

- создать единообразную судебную практику (прецедентное право) на основе решений Суда ЕC, дающих нормативное толкование Регламента «Рим I». В случае Римской конвенции 1980 г. создание такой судебной практики оказалось невозможным, поскольку Суд ЕС не получил полномочий по ее толкованию (соответствующие протоколы к Конвенции не были своевременно ратифицированы всеми государствами-членами);

- усовершенствование содержания единообразных коллизионных норм ЕС в области договорного права: например, уточнить правила относительно того, какому законодательству будет подчиняться договор, стороны которого не воспользовались предоставленной им свободой выбора применимого права (статья 4 «Право, подлежащее применению при отсутствии выбора»);

- расширение сферы применения единообразных коллизионных норм ЕС в области договорного права: например, включить специальные правила относительно договора страхования (статья 7 «Договоры страхования»).

Принцип свободы выбора в Регламенте «Рим I» закреплен также как и в Римской конвенции 1980 г. в статье 3, согласно которой договор регулируется правом, выбранным сторонами. Выбор должен быть прямо выражен или определенно вытекать из положений договора либо из обстоятельств дела. Посредством данного выбора стороны могут указать подлежащее применению право для своего договора в целом или только для отдельной его части.

Важно отметить, что в абзацах (13) и (14) Преамбулы Регламента Рим I зафиксировано, что Регламент не препятствует сторонам включить в контракт указание о применении вненациональных норм права или международного договора. В случае если Сообщество в соответствующем правовом акте установит материальные нормы договорного права, включая общие условия и типовые положения договоров, то в этом правовом акте может быть предусмотрена возможность выбора сторонами для применения данных норм.
Отвечая на вопрос, могут ли стороны договора выбирать в качестве применимого права «вненациональные» источники права, так называемое «негосударственное» право, не применяя к урегулированию отношений из договора императивных норм материального права той или иной юрисдикции, представляется, что текст Регламента не позволяет сделать однозначный вывод, возможен ли выбор источников вненационального («негосударственного» права) источников в качестве компетентного права, или их применение допустимо исключительно путем инкорпорации в текст документа. ${ }^{7}$ Однако нельзя не согласиться с Асосковым А.В., который отмечает, что если утвержденные на уровне Сообщества документы могут выступать по соглашению сторон в качестве применимого права, то иные вненациональные источники, не покрываемые действием абзаца (14) Регламента Рим I, могут быть только инкорпорированы в текст договора без устранения действия норм национального права, применимого в отсутствии выбора права согласно Регламенту. ${ }^{8}$ Необходимо подчеркнуть, что ряд стран не разделяет доктрину lex mercatoria как регулирующую систему, и Российская Федерация относится к их числу. Согласно п. 1 ст. 28 Закона РФ от 07 июля 1993 г. №5338-І любое указание на право или систему права какого-либо государства должно толковаться, как непосредственно отсылающее к материальному праву этого государства.

В российском законодательстве, регулирующем вопросы международного частного права, принцип автономии воли закреплен в п. 1 ст. 1210 Гражданского кодекса РФ. Стороны договора могут при заключении договора или в последующем выбрать по соглашению между собой право, которое подлежит применению к их правам и обязанностям по этому договору. При этом в П. 4 ст. 1210 ГК РК закреплено, что стороны договора могут выбрать подлежащее применению право как для договора в целом, так и для отдельных его частей.

Однако одновременное применение права различных государств к договору таит в себе немалый риск возникновения противоречий в регулировании отношений сторон из-за несовпадения разнонациональных норм права и может привести к полному или частичному непризнанию юридической силы соглашения о выборе права ввиду наличия неустранимых пороков содержания. ${ }^{9}$

\footnotetext{
${ }^{7}$ Гетьман-Павлова И.В., Пронюшкина Д.А. Унификация договорных обязательств в праве Европейского Союза// Международное право и международные организации. - М., 2011. -№ 5. - c. 107 -108

${ }^{8}$ Асосков A.В. Право, применимое к договорным обязательствам: европейская реформа и международное частное право//Вестник гражданского права. - М., 2009. - №2. - с.154

${ }^{9}$ Канашевский В.А. Внешнеэкономические сделки: материальноправовое и коллизионное регулирование. - М., Волтерс Клувер, 2008. - с. 126
} 


\section{Право и политика $4(160) \cdot 2013$}

Судебная практика и доктрина зарубежных стран относятся к теории расщепления довольно в определенной степени отрицательно. Кроме того, по мнению специалистов, часть договора, в отношении которой и Римская конвенция 1980 г., и Регламент «Рим І» устанавливают возможность сторонам выбрать применимое право, должна быть отделимой (severable) от остальной части контракта так, что она должна составлять подгруппу прав и обязанностей, которая может рассматриваться отдельно от основного контракта. Выбор права к различным частям договора должен быть логически совместимым и должен касаться таких элементов контракта, которые могут регулироваться различными законами без порождения противоречий. Если часть контракта, к которой избирается отдельное право, не является отделимой (severable) или выбор не является логически совместимым с правом, регулирующим остальную часть контракта, то такой выбор права судами не признается. ${ }^{10}$

Следующим важным моментом является то, что принцип автономии воли сторон должен использоваться с учетом оговорки о публичном порядке и наряду с императивными нормами. Если применение иностранного права к договору перестрахования противоречит публичному порядку страны, где происходит разбирательство спора, или страны, где будут испрашиваться в дальнейшем признание и исполнение решения, нормы такого иностранного права судами или арбитрами не применяются. Статья 16 Римской конвенции устанавливала, что в применении нормы права любой страны может быть отказано, если такая норма явно несовместима с публичным порядком страны разбирательства спора. ${ }^{11}$ В регламенте «Рим І» данный вопрос решен аналогичным способом в статье 21.

В свою очередь ст. 1193 Гражданского кодекса РФ устанавливает, что норма иностранного права, подлежащая применению в соответствии с правилами общих положений МЧП, в исключительных случаях не применяется, когда последствия ее применения явно противоречили бы основам правопорядка (публичному порядку) Российской Федерации. В этом случае при необходимости применяется соответствующая норма российского права.

В статье 9 Регламента «Рим І» в продолжении принципа, заложенного еще Римской конвенцией 1980 г. (ст. 7 Конвенции) определяется, что преобладающими императивными положениями являются положения, соблюдение которых признано страной в качестве имеющего принципиальное значение для охраны ее публичных интересов, таких как ее политическое, социальное или

\footnotetext{
${ }^{10}$ Канашевский В.А. Внешнеэкономические сделки: материальноправовое и коллизионное регулирование. - М., Волтерс Клувер, 2008. - c. 126

${ }^{11}$ Попова Е.В. Выбор применимого права при перестраховании// Хозяйство и право. - М., 2001. - №11 - с. 36
}

экономическое устройство, в такой степени, что они подлежат применению к любой ситуации, подпадающей под их действие, независимо от того, какое право в ином случае подлежало бы применению к договору согласно настоящему Регламенту. Показательно, что Римская конвенция говорила о необходимости применения императивных норм страны, с которой договор имеет тесную связь, независимо от выбора права, сделанного сторонами. При этом, суды или арбитры должны были оценивать природу, цель и последствия применения или неприменения императивных норм права такой страны. ${ }^{12}$ Положения Регламента «Рим I» уточняют данный принцип, закрепляя, что может придаваться действие преобладающим императивным положениям права страны, где возникающие на основании договора обязательства должны быть или были исполнены, в той мере, в какой эти положения делают исполнение договора незаконным. При решении вопроса о придании действия этим положениям должны учитываться их характер и цель, а также последствия их применения или неприменения.

Однако возможно, что в договоре не будет определен вопрос о выборе применимого права к договору перестрахования. В силу того, что к договорам перестрахования не применяются положения ст. 7 Регламента («О договоре страховании»), в случае отсутствия в договоре перестрахования, заключенного с иностранным элементом, указания на применимое право, то будут применяться общие положения ст. 4 Регламента. Договор будет регулироваться правом той страны, где находится обычное место жительства стороны, которая должна осуществить исполнение, имеющее решающее значение для содержания договора.

Таким образом, можно предположить, что применимым к договору международного перестрахования будет право той страны, в которой осуществляется организация договора перестрахования и проводится разрешение претензий и споров. Очевидно, что такой страной при международном перестраховании будет страна иностранного перестраховщика или, если перестрахование происходит на основе глобального распределения рисков, страна, которая является центральным местом в организации договора перестрахования (например, лондонский рынок Lloyd's). ${ }^{13}$ С учетом того, что при международном перестраховании речь идет об очень крупных рисках представляется, что наиболее характерное исполнение производит та сторона, которая несет на себе основные риски конкретного договорного отношения, т.е. перестраховшик.

В случае, если из всех обстоятельств дела вытекает, что договор имеет явно более тесные связи с другой стра-

\footnotetext{
${ }^{12}$ Попова Е.В. Выбор применимого права при перестраховании// Хозяйство и право. - М., 2001. №11 - с. 38

${ }^{13}$ Попова Е.В. Выбор применимого права при перестраховании//
} Хозяйство и право. - М., 2001. №11 - с. 39 
ной чем та, где находится обычное место жительства стороны, которая должна осуществить исполнение, имеющее решающее значение для содержания договора, то применяется право этой другой страны. Также применяется право страны, с которой договор имеет наиболее тесные связи, в случае, если подлежащее применению право не может быть определено на основании специальных правил.

Принцип «тесной связи» применяется и в российской юридической практике (ст. 1211 ГК РФ). Правом страны, с которой договор наиболее тесно связан, считается, если иное не вытекает из закона, условий или существа договора либо совокупности обстоятельств дела, право страны, где находится место жительства или основное место деятельности стороны, которая осуществляет исполнение, имеющее решающее значение для содержания договора. При этом, стороной, которая осуществляет исполнение, имеющее решающее значение для содержания договора, признается, если иное не вытекает из закона, условий или существа договора либо совокупности обстоятельств дела, сторона, являющаяся, в частности, в рамках договора страхования - страховщиком. Применяя аналогию закона, полагаем, что возможно констатировать, что стороной, которая осуществляет исполнение в соответствии с российским законодательством по договору перестрахования, является перестраховщик.

В настоящее время в виду отсутствия коллизионного регулирования перестраховочных отношений в целом в России, а также с учетом рассмотренного европейского регулирования правил о выборе применимого права, целесообразно рассмотреть вопрос о дополнении п. 3 ст. 1211 ГК РФ положением, указывающим, что стороной, которая осуществляет исполнение, имеющее решающее значение для содержания договора, признается, если иное не вытекает из закона, условий или существа договора либо совокупности обстоятельств дела, сторона, являющаяся перестраховщиком в договоре перестрахования.

Российским страховым организациям, выступающим в качестве перестрахователей при заключении договоров перестрахования с зарубежным партнерам (перестраховщикам), работающим или планирующим работу на международном перестраховочном рынке, следует очень внимательно относиться к вопросу о выборе применимого права и по возможности прямо предусматривать применимое право к договору перестрахования, в соответствии с которым будут рассматриваться возникающие споры.

Необходимо учитывать, что развитый гражданский оборот предполагает существование таких обязательств, в которых с одной и (или) с другой стороны участвует одновременно несколько лиц (несколько кредиторов и (или) должников). В обязательстве всегда должно быть как минимум две стороны: кредитор и должник. Однако понятие стороны в обязательстве не совпадает с понятием субъекта обязательства. Сторон в обязательстве может быть две, а субъектов больше. Это обстоятельство с неизбежностью вызывает необходимость специального регулирования отношений в обязательстве с множественностью лиц, в том числе и отношений по исполнению этих обязательств. ${ }^{14}$ Применительно к договорам международного перестрахования примером может послужить ситуация, когда на стороне страхователя один субъект, а на стороне перестраховщика два и более.

Множественность лиц на стороне перестраховщика достаточно частое явление, особенно в таких видах договоров перестрахования, как облигаторные договоры перестрахования. Регулирование такого договора может быть осложнено тем обстоятельством, что участники договора перестрахования могут быть из различных юрисдикций: не двух, и даже не трех, а из пяти и более. Соответственно в случае, если стороны не определили право применимое к заключенному договору, то представляется, что определить применимое право по правилу о месте регистрации стороны, которая должна осуществлять исполнение, достаточно проблематично, т.к. установление применимого права должно отвечать критерию определенности. Правило о «наиболее тесной связи» также ставит определение применимого права в зависимость от усмотрения суда, выбор которого может оказаться невыгодным с точки зрения реализации прав и исполнения обязанностей для одной из сторон по договору перестрахования. С учетом изложенного представляется, что в таких сделках, как договор международного перестрахования, осложненных множественностью лиц на стороне перестраховщика, определение применимого права при заключении договора перестрахования должно быть обязательным условием заключения такого договора.

Законодательство ряда стран ограничивает для сторон сделки возможность выбора применимого права лишь правовыми системами тех государств, с которыми сделка имеет определенную связь. Так, ст. 1-105 Единообразного торгового кодекса США говорит о необходимости существования «разумной» связи с применимым правом. Вопрос о применимом праве является существенным в коммерческой практике США, т.к. наблюдается различное отношение законодателя к автономии воли сторон. Американское законодательство по вопросу о выборе применимого права сторонами контракта содержит различные правила как на федеральном уровне, так и на уровне штатов. Более того, законы отдельных штатов существенно отличаются друг от друга по данному вопросу. Например, законодательство отдельных штатов может устанавливать требование, что избранное право должно иметь отношение либо к сторонам контракта, либо к сделке. Это дает возможность суду или арбитрам

${ }^{14}$ Сарбаш С.В. Обязательства с множественностью лиц и особенности их исполнения. - М.: Статут, 2004 г. - с. 57 


\section{Право и политика 4 (160) 2013}

отступить от избранного сторонами права, если это право третьей, нейтральной страны. ${ }^{15}$

Например, согласно Закона об общих обязательствах штата Нью-Йорк (ст.5-1401) разрешается применение законодательства штата Нью-Йорк к сделке, не имеющей связи с этим штатом. Для этого необходимы следующие условия: стороны должны заключить соглашение о применении права штата Нью-Йорк к их сделке; сделка должна быть коммерческой, за исключением контрактов для личных нужд и внутриамериканских сделок; сумма контракта должна быть не менее 250 тыс. долларов.

Еще один важный блок вопросов, подлежащий определению сторонами договоров международного перестрахования - это выбор органа и способа разрешения споров. Основные судебные учреждения, разрешающие внешнеэкономические споры в России и в иностранных государствах, - это государственные суды и третейские суды (институционные и ad hoc).

Компетенция государственных арбитражных судов по рассмотрению дел с участием иностранных лиц определяется в гл. 32 Арбитражного процессуального кодекса Российской Федерации 2002 г. ${ }^{16}$ Согласно ст. 247 АПК РФ арбитражные суды в Российской Федерации рассматривают дела по экономическим спорам и другие дела, связанные с осуществлением предпринимательской и иной экономической деятельности, с участием иностранных организаций, международных организаций, иностранных граждан, лиц без гражданства, осуществляющих предпринимательскую и иную экономическую деятельность (далее - иностранные лица), в случае, если ответчик находится или проживает на территории Российской Федерации либо на территории Российской Федерации находится имущество ответчика; орган управления, филиал или представительство иностранного лица находится на территории Российской Федерации; спор возник из договора, по которому исполнение должно иметь место или имело место на территории Российской Федерации; требование возникло из причинения вреда имуществу действием или иным обстоятельством, имевшими место на территории Российской Федерации, или при наступлении вреда на территории Российской Федерации; а также при наличии тесной связи спорного правоотношения с территорией Российской Федерации.

Арбитражные суды в Российской Федерации рассматривают также экономические споры и другие дела, связанные с предпринимательской и иной экономической

\footnotetext{
${ }^{15}$ O. Мата. Правомерность выбора применимого права сторонами контракта: опыт США// Российская юстиция. - М.: Юрид. лит., 2002. - № 8. - c. 52

16 Федеральный закон от 24 июля 2002 г. №96-Ф3 «О введении в действие Арбитражного процессуального кодекса Российской Федерации» // С3 РФ. 2002 г. №30. Ст. 3013.
}

деятельностью с участием иностранных лиц, в том числе отнесенные к их исключительной компетенции, в частности, по спорам, связанным с учреждением, ликвидацией или регистрацией на территории Российской Федерации юридических лиц и индивидуальных предпринимателей, а также с оспариванием решений органов этих юридических лиц. При этом, если стороны заключили соглашение, в котором определили, что арбитражный суд в Российской Федерации обладает компетенцией по рассмотрению возникшего или могущего возникнуть спора, связанного с осуществлением ими предпринимательской и иной экономической деятельности, арбитражный суд в Российской Федерации будет обладать исключительной компетенцией по рассмотрению данного спора при условии, что такое соглашение не изменяет исключительную компетенцию иностранного суда. Важно отметить, что соглашение об определении компетенции должно быть заключено в письменной форме (п. 2 ст. 249 АПК РФ).

Обращение сторон не к государственному, а к третейскому суду в области международных экономических связей объясняется тем, что одна из сторон не верит в объективность судопроизводства в другой стране. Делая выбор в пользу третейского суда, стороны исходят из следующих соображений:

- срок рассмотрения дел в третейском суде, как правило, короче, чем в обычном суде;

- профессиональная компетентность арбитров, которые должны рассматривать спор, обычно выше, чем судей в государственных судах, поскольку последние не обладают специальными знаниями и опытом ведения операций в области международной торговли, валютного регулирования, торгового мореплавания и в других аналогичных сферах;

- решение арбитража, как правило, не подлежит обжалованию;

- предусматривается возможность согласования между сторонами языка, на котором будет вестись разбирательство дела в арбитраже;

- для фирм, ведущих споры, важно соблюдение конфиденциальности, а третейский суд обычно заседает негласно, его решения обычно не публикуются, а если и публикуются, то без указания наименований спорящих сторон и уж во всяком случае без приведения сведений о суммах исковых требований. ${ }^{17}$

Возможность признания и исполнения иностранных арбитражных решений была создана благодаря участию широкого круга государств в Нью-Йоркской конвенции 1958 г. Высший Арбитражный Суд РФ в Информационном письме от 1 марта 1996 г. №ОМ-37 разъяснил, что эта Конвенция регулирует вопросы взаимного признания

${ }^{17}$ Богуславский М.М. Международное частное право: Учебник. М.: Юрист, 2005. - с. 276 
и исполнения на территории государств - участников Конвенции не судебных, а арбитражных решений, т.е. решений, принятых на территории другого государства арбитражами, избираемыми сторонами в международном коммерческом споре или назначенными органами коммерческого арбитража. Эти органы, отмечается далее в Информационном письме, именуются по терминологии, принятой в нашей стране, третейскими судами. ${ }^{18}$

В рамках Европейского Союза, кроме Дании, до 2002 г. действовала Брюссельская конвенция о юрисдикции и приведении в исполнение судебных решений по гражданским и торговым делам от 27 сентября 1968 г., заключенная государствами-членами ЕС, основываясь на положениях абзаца 4 статьи 293 Договора о создании ЕС. Конвенция содержала детальную регламентацию правил международной подсудности, действующей на территории ЕС. 16 сентября 1988 г. государства-члены ЕС и государства Европейской Ассоциации свободной торговли заключили Луганскую конвенцию «О юрисдикции и исполнении судебных решений по гражданским и коммерческим делам», которая была аналогична тексту Брюссельской конвенции 1968 г. Была проделана большая работа по пересмотру данных Конвенций, и Совет ЕС одобрил содержание исправленных текстов. Результаты проделанной работы явились основой нового документа, посвященного вопросам юрисдикции и исполнении судебных решений. С 1 марта 2002 г. вступил в силу Регламент Совета ЕC N 44/2001 от 22 декабря 2000 г. о юрисдикции, признании и исполнении решений по гражданским и коммерческим делам.

В связи с тем, что различия национальных правил, регулирующих юрисдикцию и признание судебных решений, затрудняют устойчивое функционирование внутреннего рынка ЕС, основной целью Регламента является унификация коллизионных норм по гражданским и коммерческим делам, а также упрощение формальностей с целью ускорения и облегчения процедуры признания и исполнения судебных решений государствами-членами ЕС.

Раздел 3 Регламента устанавливает правила выбора юрисдикции по делам, относящимся к страхованию. К страховщику, имеющему постоянное место нахождения в государстве-члене ЕС, может быть предъявлен иск: а) в судах государства-члена ЕС, где он постоянно находится; b) в другом государстве-члене ЕС, в случае, когда иск предъявлен держателем страхового полиса, застрахованным лицом или бенефициаром, - в судах по месту постоянного нахождения истца; с) если он является состраховщиком - в судах государства-члена ЕС, в котором рассматривается дело в отношении основного страховщика.

Регламент не содержит специальных правил, относящихся к договорам перестрахования. Однако пред-

${ }^{18}$ Богуславский М.М. Международное частное право: Учебник. М.: Юрист, 2005. - c. 276 ставляется, что к договорам перестрахования изложенные правила ст. 8 Регламента должны применяться по аналогии. Согласно ст. 22 Регламента исключительной юрисдикцией, независимо от постоянного местонахождения сторон, обладают суды государств-членов ЕС, в котором решение было или должно быть приведено в исполнение, относительно исков, касающихся приведения в исполнение судебных решений.

Как уже было отмечено, помимо разрешения споров в судебном порядке, международно - правовая практика выработали систему «альтернативных», т.е. дополнительных способов урегулирования споров во внешнеэкономической деятельности. ${ }^{19}$

В качестве «альтернативных» способов применяются, в частности, следующие:

- медиация (посредничество);

- примирительное производство;

- независимая оценка;

- мини - процесс.

В российской доктрине деление способов разрешения споров на мирные и конфликтные пока не устоялось, чаще выделяются судебные и внесудебные способы разрешения спора. Последние иногда отождествляются с досудебным порядком урегулирования разногласий. Данная классификация предопределяется содержанием действующих в Российской Федерации Арбитражного процессуального и Гражданского процессуального кодексов. При этом российское законодательство не содержит общего понятия альтернативных способов разрешения споров, а регулирует лишь отдельные способы, причем некоторые весьма отрывочно. ${ }^{20}$ Согласно Арбитражному процессуальному кодексу судья в процессе подготовки к судебному разбирательству разъясняет сторонам право обратиться содействием к посреднику в целях урегулирования спора, помимо обращения к третейскому суду, (ст. 135 АПК РФ). Как уточняется в пункте 13 Постановления Пленума ВАС РФ от 20 декабря 2006 года № 65 «О подготовке дела к судебному разбирательству», судья «разъясняет сторонам не только их право заключить мировое соглашение, передать дело на рассмотрение третейского суда, обратиться за содействием к посреднику, но и существо и преимущества примирительных процедур, а также правовые последствия этих действий».

За рубежом, а также на международном уровне мирные способы разрешения споров используются более активно, в частности, в международном экономическом обороте.

\footnotetext{
19 Белов А. Альтернативные способы разрешения внешнеэкономических споров// Право и экономика - М., 1998 г. - №6 . - с. 37

${ }^{20}$ Ванеев А. Мирные способы разрешения споров в российской и международной практике. Приложение к русскому изданию книги Левина С. Разрешение конфликтов: от конфликта к сотрудничеству / пер. с англ. - М.: Олимп-бизнес, 2008 г. - с. 241-242
} 


\section{Право и политика 4 (160) • 2013}

Указанные «альтернативные» способы урегулирования споров характеризуются следующими основными чертами:

1. Они не являются судебными или арбитражными способами и сторон их используют в тех случаях, когда возникшие споры могут привести к нарушению сложившихся между ними долговременных отношений. Это попытка сохранить хорошие отношения, не прибегая при этом к принудительному производству через суд или арбитраж.

2. Использовать указанные способы можно лишь при обоюдном согласии на это спорящих сторон. Результат обращения к использованию указанных способов будет являться обязательным для сторон только в тех случаях, когда стороны достигли и заключили соглашение, содержащее условия разрешения спора. До подписания соглашения любая сторона имеет право отказаться от урегулирования спора указанными средствами и обратиться в суд или арбитраж или продолжить начатый процесс в этих учреждениях.

3. Процедура «альтернативного» способа урегулирования спора осуществляется на конфиденциальной основе. Если стороны не пришли с соглашению при ее использовании, то в случае последующего обращения в суд или арбитраж ни одна из сторон не вправе ссылаться на те вопросы и использовать позицию сторон, которые были предметом рассмотрения во время альтернативной процедуры.

4. «Альтернативный» способ урегулирования спора позволяет сторонам найти те решения, которые отвечали бы их коммерческим интересам и потребностям, и форма процедуры может быть подобрана под них.

5. По сравнению с судебным или арбитражным производством «альтернативный» способ урегулирования спора не является дорогостоящей процедурой, особенно если стороны пришли к соглашению и в связи с этим не обращались в суд или арбитраж. Для этой процедуры характерна быстрота урегулирования споров. ${ }^{21}$

Одним из наиболее распространенных способов разрешения споров, вытекающих из договоров перестрахования является медиация, который представляет собой формальный процесс согласования позиций, осуществляемый при активном участии нейтрального лица (медиатора), выбранного совместно сторонами спора.

Большинство из споров, вытекающих из договоров перестрахования, разрешаются мирным путем. И всего лишь небольшая часть споров рассматривается в судебном порядке до вынесения решения. Чаще всего стороны договоров перестрахования стремится к мирному урегулированию спора, однако не знает каким образом

${ }^{21}$ Белов А. Альтернативные способы разрешения внешнеэкономических споров// Право и экономика - М., 1998 г. - №6. - с. 37 добиться данного результата без лишних временных и материальных затрат. ${ }^{22}$

Целью медиации является не определение того, кто прав, а нахождение компромиссного решения, которое станет наилучшим для обеих сторон. Для того чтобы проведение медиации по спору было в принципе возможно, необходимо согласие на это сторон спора. Такое соглашение должно иметь письменную форму и может как быть частью заключенного между сторонами договора, из-за которого возникло разногласие, так и являться отдельным документом, составленным до или после возникновения спора. Результатом процедуры медиации обычно является соглашение между сторонами. ${ }^{23}$

Это соглашение не может быть принудительно исполнено, не предусматривается и оспаривание такого соглашения. В России ряд действующих правил медиации предусматривают способ, который позволяет принудительно привести положения соглашения в исполнение. Это можно сделать путем обращения в третейский суд с тем, чтобы достигнутое соглашение было оформлено в качестве его решения. Впоследствии это решение может быть приведено в исполнение в порядке, предусмотренном главой VIII Ф3 «О третейских судах в РФ» и параграфом 2 главы 30 АПК РФ.

Одной из особенностей споров, вытекающих из договоров перестрахования, осложненных иностранным элементом, является то, что местом разрешения подобных споров чаще всего выступает коммерческий арбитражный суд (третейский суд): либо институциональный арбитраж, либо арбитраж ad hoc.

Институциональным арбитражем при разрешении споров в области страхования и перестрахования является AIDA Insurance and Reinsurance Arbitration Society (ARIAS) (Арбитражное сообщество страховщиков и перестраховщиков). Это некоммерческое сообщество было образовано в 1991 году в Великобритании, а в 1994 г. в США по инициативе различных представителей юридической профессии в целях совершенствования процедуры арбитражного разбирательства в области страхования и перестрахования. Арбитражное сообщество, как в Великобритании, так и в США объединяет высококвалифицированных арбитров и служит ресурсом для сторон, участвующих в споре, при поиске арбитров для разрешения спорного вопроса наиболее профессиональным и экономически эффективным образом.

Оговорка о юрисдикции и применимом праве (Arbitration and Applicable Law) в договоре перестрахо-

\footnotetext{
${ }^{22}$ Katherine L.Billingham. Mediation in Reinsurance// ARIAS US. Vol. 19, No.2, Second Quarter, 2012 - p.19

${ }^{23}$ Ванеев А. Мирные способы разрешения споров в российской и международной практике. Приложение к русскому изданию книги Левина С. Разрешение конфликтов: от конфликта к сотрудничеству / пер. с англ. - М.: Олимп-бизнес, 2008 г. - с. 243
} 
вания позволяет определить страну, правовым нормам которой подчиняется договор, порядок разрешения споров между сторонами договора, место проведения арбитражного разбирательства, если сторонам не удалось разрешить спорные вопросы без участия третьей стороны.

Приведем пример оговорки о юрисдикции, основанной на применении правил специализированного международного коммерческого арбитража в Великобритании - ARIAS UK.

Все разногласия и разночтения, возникающие в связи с действием настоящего Договора должны регулироваться Арбитражными правилами Арбитражного сообщества страховщиков и перестраховщчиков (ARIAS). Арбитражный суд должен состоять из трех судей, один из которых назначается Истиом, один назначается Ответчиком, а третий назначается двумя вымеозначенным судьями. Третий судья должен быть назначен в кратчайшие сроки (не позднее 28 дней) после назначения первых двух судей, назначенных Истиом и Ответчиком. Суд считается учрежденным после назначения третьего судьи.

Судьи должны обладать (включая тех, кто ушел в отставку) опытом работы в страховой и перестраховочной сфере. Судьи могут быть назначены из числа адвокатов или профессиональных консультантов с опытом не менее 10 лет.

В случае, если одна из сторон в течение 14 дней с момента предписания сделать это не назначает судью, или двое судьей, назначенные Истцом и Ответчиком в течение 28 дней с момента их назначения не утвердили кандидатуру третьего судью, третий судья будет определен Арбитражным сообществом страховщиков и перестраховщиков. В любое время до назначения третьего судьи Арбитражным сообществом страховщиков и перестраховщиков одна из сторон или судьи могут произвести данное назначение.

Суд имеет право по собственному усмотрению делать такие распоряжения и указаний, которые необходимы для окончательного определения спорных вопросов. Суд имеет наиболее иирокое усмотрение, допустимое в соответствии с законодательством, регулирующим арбитражную процедуру, при вынесении таких распоряжений и указаний.

Заседаниесудадолжно проходить в Настоящий договор регулируется правом

Приведем пример оговорки о юрисдикции, предусматривающей создание арбитража ad hoc из числа наиболее авторитетных специалистов в области правового регулирования отношений страхования и перестрахования, а также в сфере страхования в целом.

Все разногласия и разночтения, возникшие в рамках настоящего Договора в отношении срока действия, толкования, исполнения либо прекращчения обязательств, которые не могут быть разрешены мирным путем, должны быть рассмотрены Арбитражным Судом согласно нижеописанной процедуре.

Одни и те же вопросы могут иметь различное значение для компании Перестрахователя, Перестраховщчка и одной или несколькими компаниями, участвующими в перестраховании прямого договора страхования. В этом случае ничто в настоящем Договоре не должно препятствовать согласию всех участников настоящего Договора или тех, кого затрагивает спорное правоотношение, следовать решению Арбитражного суда.

Каждая сторона выбирает Судью, который будет являться незаинтересованным лицом, занимающий в настоящее время либо занимавший до выхода на пенсию позииию директора страховой или перестраховочной компании в сфере кредитного страхования, или юриста или другого профессионального консультанта в данной области отношений. Перед началом судебных заседаний по рассмотрению спора двое Судей обязаны выбрать третьего Судью, который будет исполнять обязанности Председателя Арбитражного суда. Ни при каких обстоятельствах они не могут быть сторонами по делам, переданным на рассмотрение арбитражного суда.

Аналогичный процесс применяется в случае отставки или смерти Судьи в отношении назначения замены.

Местом проведения заседаний Арбитражного суда признается офис Перестрахователя, применимое право _. Язык, который будет использоваться на заседаниях Арбитражного суда, язык компании Перестрахователя, за исключением, если Судьи не решат иначе.

Арбитражный суд должен следовать положениям законодательства и должен иметь полномочия устанавливать все проиессуальные нормы для проведения судебного заседания, включая дискреичонные полномочия издавать приказы относительно любых спорных вопросов, которые он сочтет должными при данных условиях или в случае прений сторон в Суде, раскрытии и инспекичи документов, допроса свидетелей и любых других вопросов, связанных с проведением судебного заседания, а также может работать со свидетельствами, будь то они устными или письменными, строго приемлемыми или нет, поскольку это должно считаться иелесообразным по усмотрению Суда. Суд должен выносить решения на основании практики страхования и перестрахования кредитных рисков.

Решение Суда должно быть принято большинством судей. В том случае, если решение не может быть принято большинством голосов, то решение третий Судья превалирует.

Решение Арбитражного суда должно быть принято в течение 3-х месяцев после создания Арбитражного суда. 


\section{Право и политика 4 (160) • 2013}

Решение Арбитражного суда должно быть оформлено в письменной форме и содержать обоснование решения, которое было принято. Решение является обязательным для обеих сторон и не подлежать обжалованию. Все судебные издержки должны быть определены Арбитражным судом, который может, принимая во внимание законодательство, определить, кто и в каком порядке будет платить.

Председатель Арбитражного суда несет ответственность за доведение решения, принятого Арбитражным судом, до сведения сторон и обеспечение исполнения указанного решения.

Как уже отмечалось, многие российские страховые организации для защиты рисков, принятых на страхование, в основном заключают договоры перестрахования с зарубежными партнерами (чаще всего находящимися в Западной Европе, США). В этой связи вопросы выбора применимого права и юрисдикции становятся основополагающими и подлежат разрешению путем включения в договор перестрахования оговорок о применимом праве и юрисдикции. Соответственно определение места, правил разрешения споров, также как и определение применимого права при заключении договора перестрахования являются обязательными условиями заключения договоров перестрахования, осложненных иностранным элементом.

Главное преимущество арбитражного способа рассмотрения споров перед передачей спора в государственный суд для российских организаций и их партнеров состоит в том, что решение иностранного суда, в отличие от решения иностранного арбитража, возможно будет исполнить только в тех странах, с которыми Россия заключила двусторонние договоры о правовой помощи, предусматривающие взаимное признание и исполнение судебных решений. Таких договоров у России заключено около четырех десятков.

Стороны договора перестрахования должны четко определить условие о выборе соответствующей юрисдикции и применимого права для того, чтобы впоследствии не возникало спорных ситуаций, не порождало риска отмены арбитражного решения или отказа от принудительного исполнения арбитражного решения, рассмотренного на основании материального права, определенного арбитрами согласно свободе усмотрения.

Материальное право различных государств существенно различается. Урегулирование спорной ситуации, возникшей между сторонами договора перестрахования, осложненного иностранным элементом, включая вопросы о пределах ответственности сторон по договору, действительности и действии договора перестрахования, зачастую зависит от того, какому правопорядку подчинен данный договор, а также какой орган и способ разрешения споров выбрали участники договора.

\section{Библиография:}

1. Федеральный закон от 24 июля 2002 г. №96-Ф3 «О введении в действие Арбитражного процессуального кодекса Российской Федерации» // С3 РФ. 2002 г. №30. Ст. 3013.

2. Ануфриева Л.П. Международное частное правом: в 3-х т. Особенная часть, Том 2- М.: Издетельство БЕК, 2002.

3. Асосков А.В. Право, применимое к договорным обязательствам: европейская реформа и международное частное право// Вестник гражданского права. - М., 2009. - №2.

4. Белов А. Альтернативные способы разрешения внешнеэкономических споров// Право и экономика - М., 1998 г. - №6.

5. Богуславский М.М. Международное частное право: Учебник. - М.: Юрист, 2005.

6. Ванеев А. Мирные способы разрешения споров в российской и международной практике. Приложение к русскому изданию книги Левина С. Разрешение конфликтов: от конфликта к сотрудничеству / пер. с англ. - М.: Олимп-бизнес, 2008 г.

7. Гетьман-Павлова И.В., Пронюшкина Д.А. Унификация договорных обязательств в праве Европейского Союза// Международное право и международные организации. - М., 2011. -№ 5.

8. Доклад о развитии страхового рынка в России в 2009 году - 1 полугодии 2010 года// Федеральная служба страхового надзора. Доклад опубликован на сайте Федеральной службы страхового надзора PФ. URL: http://www.fssn.ru/www/site.nsf/web/ doc_21042011152741.html

9. Зимин А.В. Кому нужен старый комод, или Снова о перестраховании// Юридическая и правовая работа в страховании. - М., 2012. - № 4 (32).

10. Канашевский В.А. Внешнеэкономические сделки: материально-правовое и коллизионное регулирование. - М., Волтерс Клувер, 2008.

11. Мата О. Правомерность выбора применимого права сторонами контракта: опыт США// Российская юстиция . - М.: Юрид. лит., 2002. - № 8 .

12. Попова Е.В. Выбор применимого права при перестраховании// Хозяйство и право. - М., 2001. - №11.

13. Сарбаш С.В. Обязательства с множественностью лиц и особенности их исполнения. - М.: Статут, 2004 г.

14. Сироткина О.В. Принципы европейского договорного права: история создания, статус и основные положения // Сборник научных трудов. Серия «Право», выпуск № 1 (5). - СевКавГТУ, Ставрополь, 2003.

15. Katherine L.Billingham. Mediation in Reinsurance// ARIAS US. Vol. 19, No.2, Second Quarter, 2012. 
Юридический практикум

\section{References (transliteration):}

1. Anufrieva L.P. Mezhdunarodnoe chastnoe pravom: v 3-kh t. Osobennaya chast', Tom 2-M.: Izdetel'stvo BEK, 2002.

2. Asoskov A.V. Pravo, primenimoe k dogovornym obyazatel'stvam: evropeyskaya reforma i mezhdunarodnoe chastnoe pravo// Vestnik grazhdanskogo prava. -M., 2009. - №2.

3. Belov A. Al'ternativnye sposoby razresheniya vneshneekonomicheskikh sporov// Pravo i ekonomika - M., 1998 g. - №6.

4. Boguslavskiy M.M. Mezhdunarodnoe chastnoe pravo: Uchebnik. - M.: Yurist, 2005.

5. Vaneev A. Mirnye sposoby razresheniya sporov v rossiyskoy i mezhdunarodnoy praktike. Prilozhenie k russkomu izdaniyu knigi Levina S. Razreshenie konfliktov: ot konflikta k sotrudnichestvu / per. s angl. - M.: Olimp-biznes, 2008 g.

6. Get'man-Pavlova I.V., Pronyushkina D.A. Unifikatsiya dogovornykh obyazatel'stv v prave Evropeyskogo Soyuza// Mezhdunarodnoe pravo i mezhdunarodnye organizatsii. - M., 2011. - № 5.
7. Zimin A.V. Komu nuzhen staryy komod, ili Snova o perestrakhovanii// Yuridicheskaya i pravovaya rabota $\mathrm{v}$ strakhovanii. - M., 2012. - № 4 (32).

8. Kanashevskiy V.A. Vneshneekonomicheskie sdelki: material'no-pravovoe i kollizionnoe regulirovanie. - M., Volters Kluver, 2008.

9. Mata O. Pravomernost' vybora primenimogo prava storonami kontrakta: opyt SShA// Rossiyskaya yustitsiya. - M.: Yurid. lit., 2002. - № 8 .

10. Popova E.V. Vybor primenimogo prava pri perestrakhovanii// Khozyaystvo i pravo. - M., 2001. - №11.

11. Sarbash S.V. Obyazatel'stva s mnozhestvennost'yu lits i osobennosti ikh ispolneniya. - M.: Statut, 2004 g.

12. Sirotkina O.V. Printsipy evropeyskogo dogovornogo prava: istoriya sozdaniya, status i osnovnye polozheniya // Sbornik nauchnykh trudov. Seriya “Pravo", vypusk № 1 (5). - SevKavGTU, Stavropol', 2003.

13. Katherine L.Billingham. Mediation in Reinsurance// ARIAS US. Vol. 19, No.2, Second Quarter, 2012. 